\title{
IMPROVEMENT AND OPTIMISATION OF GYROPLANE PERFORMANCE
}

\author{
WIEŃCZYSLAW STALEWSKI \\ Institute of Aviation, Al. Krakowska 110/114, 02-256 Warsaw, Poland \\ Wienczyslaw.Stalewski@ilot.edu.pl
}

\begin{abstract}
The aim of this study was to investigate possibilities of improving performance characteristics of light gyroplane, as well to propose new or improved solutions enhancing performance of this type of rotorcraft. The study has been conducted based on computational methods of Computational Fluid Dynamics, Flight Dynamics, Computer Aided Design and Optimisation. Results of the research confirm that using advanced computational methods it is possible to improve significantly the performance characteristics of light gyroplane. It can be achieved both through optimisation of the main rotor design and flight control strategy. An unconventional approach to rotorcraft optimisation has been presented, distinguishing by the fact that the objective was calculated based on computer simulations of selected states of gyroplane flight. One of the optimised main rotors had already been examined during flight tests, which confirmed its good performance-and-exploitation properties and its advantage over classic gyroplane rotors. Developed by the author the family of gyroplane airfoils is a valuable alternative to classic airfoils utilised so far. The same applies to the blades built based on those airfoils. In particular, it concerns the unconventional design of the rotor blade of span-variable: chord and relative thickness. The developed methodology of numerical optimisation of flight-control strategy during the jump takeoff of the gyroplane presents an original approach to those problems and may be valuable tool supporting gyroplane-pilot training.
\end{abstract}

Keywords: rotorcraft performance, gyroplane, jump takeoff, main rotor, design and optimisation.

\section{NOMENCLUATURE}

$\mathrm{C}_{\mathrm{D}} \quad-$ drag coefficient

$\mathrm{C}_{\mathrm{L}} \quad-$ lift coefficient

$\mathrm{C}_{\mathrm{Lmax}}$ - maximum lift coefficient

$\mathrm{C}_{\mathrm{m}} \quad$ - pitching moment coefficient

D - drag force generated by the rotor

$\mathrm{H}-$ momentary altitude of gyroplane flight

$\mathrm{I}_{\mathrm{R}} \quad-$ rotor moment of inertia

L - lift force generated by the rotor

M - Mach number
Re - Reynolds number

t - time

$\mathrm{V}_{\mathrm{f}}-$ local flow velocity

$\mathrm{V}$ - flight velocity

$\mathrm{X}$ - distance travelled by the gyroplane

$\varphi_{\mathrm{R}} \quad$ - pitch angle of the rotor

$\theta_{0}-$ collective pitch of rotor blades

$\theta_{\mathrm{P}}-$ collective pitch of propeller blades

$\Omega_{\mathrm{R}} \quad$ - rotor rotational speed 


\section{INTRODUCTION}

An gyroplane also known as autogyro has been invented by the Spanish engineer Juan de la Cierva to create an aircraft that could fly safely at low speeds [2]. In a classic gyroplane, lift force is generated by unpowered rotor operating in autorotation and drag force is balanced by the engine-powered propeller [21]. The pitch-and-roll control is conducted by longitudinal and lateral tilting of the rotor. During the gyroplane flight the air flowing around rotating blades generates aerodynamic reaction whose vertical component balances the gyroplane weight, while the aerodynamic moment is driving the main rotor.

In classic gyroplane there are only three flight controls: a control stick, rudder pedals and a throttle [7]. Aircraft pitch and roll is controlled by a conventional joystick coupled to the rotor. A simple set of rudder pedals move the rudder on the vertical stabilizer, which ensures the yaw control of the aircraft.

Typical gyroplane main rotors are characterised by a simple design, especially in the case of rotors of light gyroplanes. They are usually two-bladed, teetering rotors. Their blades have a rectangular planform, uniform spanwise distribution of airfoil and usually are not twisted. Typical airfoils used on gyroplane-main-rotor blades are NACA8H12 [8],[19] or NACA9H12 [19]. Usually, the gyroplane rotor has a fixed collective pitch of the blades and does not have a cyclic-pitch control. However, to enhance the gyroplane controllability and manoeuvrability designers introduce the collective-pitch control in a rotor-head design, which is especially important when planning to perform so-called "jump takeoff" - the manoeuvre in which the gyroplane takes off similarly to a helicopter, without the accelerating run along a runway.

The studies described in the paper are focused on improving the gyroplane performance through an optimal design of the gyroplane main rotor as well as through optimisation of flight-control strategies, especially during the jump takeoff. The main goals of the research were:

- to design aerodynamically improved main rotors intended for light gyroplanes,

- to optimise the moment of inertia of the rotor so as to improve jump-takeoff performance of the gyroplane,

- to optimise jump-takeoff-control strategy.

The investigation has been conducted on the basis of computational methods of fluid dynamics and flight dynamics as well as based on aircraft-design-and-optimisation methods.

Although the presented research can be generalized to a generic gyroplane, the study has focused mainly light gyroplanes produced by the Polish aviation industry. As part of the domestic project "Modern Gyroplane Main Rotor" the research have aimed at development and application of new technologies related to the light-gyroplane main rotors, which was supposed to increase the competitiveness of this type of aircraft produced by the domestic industry. According to the main guidelines of the project, the research presented in the paper focused on innovative technologies introduced in the main-rotor design, towards improvement of aerodynamic properties and performance of contemporary and future light gyroplanes.

Previously, studies on the possibilities of improving of light-gyroplane performance were carried out, among others, in relation to the light gyroplane designed in the Institute of Aviation [3],[4],[15],[16],[17],[20].

The research being a subject of this paper has been presented by the author in a wider form in the book [14]. 


\section{RESEARCH METHODOLOGY}

The investigations aiming at improvement and optimisation of light-gyroplane performance were conducted in several stages and were focused on two main topics:

- designing and optimisation of the gyroplane main rotor, especially in fast-flight conditions

- optimisation of the gyroplane performance during the jump takeoff

The process of optimisation of main rotors intended for light gyroplanes was conducted within three main stages. The first stage was focused on design of family of gyroplane airfoils. The second stage concerned the design and optimisation of rotor blades, based on the newly designed airfoils. The third stage was focused on aerodynamic design and optimisation of gyroplane main rotors, seen as systems of previously designed blades. This stage included studies on optimal choice of blade-collective-pitch control as well as studies on optimal strategy of rotor-pitch-and-roll control in so-called jump takeoff.

\subsection{Methodology of Design of Gyroplane-Airfoil Family}

The design of airfoils intended for the gyroplane-rotor blades was conducted simultaneously with rotor blades design. The new airfoils were designed so as to fulfil requirements defined based on an analysis of aerodynamic properties of subsequent variants of gyroplane main rotors. The starting point for the airfoil design was the airfoil NACA9H12M which was a slightly modified version of the airfoil NACA9H12 commonly used in designing gyroplane-rotor blades. The optimisation of airfoils was conducted with the use of the following computational tools:

- CODA4W - in-house code supporting airfoil design,

- INVDES - in-house code solving the Inverse-Airfoil-Design problem,

- XFLR-5 [5] - commonly used code for aerodynamic analysis of airfoils in low-speed conditions,

- ANSYS FLUENT [1] - commonly used Navier-Stokes-Equation solver.

During the design of a new family of airfoils, their initial shapes were designed using the CODA4W software. Next the airfoils were redesigned and smoothed aerodynamically by the solution of InverseAirfoil-Design problem. Aerodynamic properties of subsequent variants of airfoils were analysed using the XFLR-5 software. For selected airfoils, the databases of aerodynamic characteristics were built with the use of the ANSYS FLUENT code.

\subsection{Methodology of Simulation of Gyroplane Flight}

The general scheme of the developed methodology for rotorcraft-flight simulation is presented in Fig. 1. The flight-simulation procedure is embedded in the URANS solver ANSYS FLUENT. Flow effects caused by rotating lifting surfaces are modelled by application of the developed Virtual Blade Model (VBM) [14],[18].

In this approach real rotors are replaced by volume discs influencing the flow field similarly as rotating blades. Time-averaged aerodynamic effects of rotating lifting surfaces are modelled by means of artificial momentum source terms placed inside the volume-disc zones placed in regions of activity 


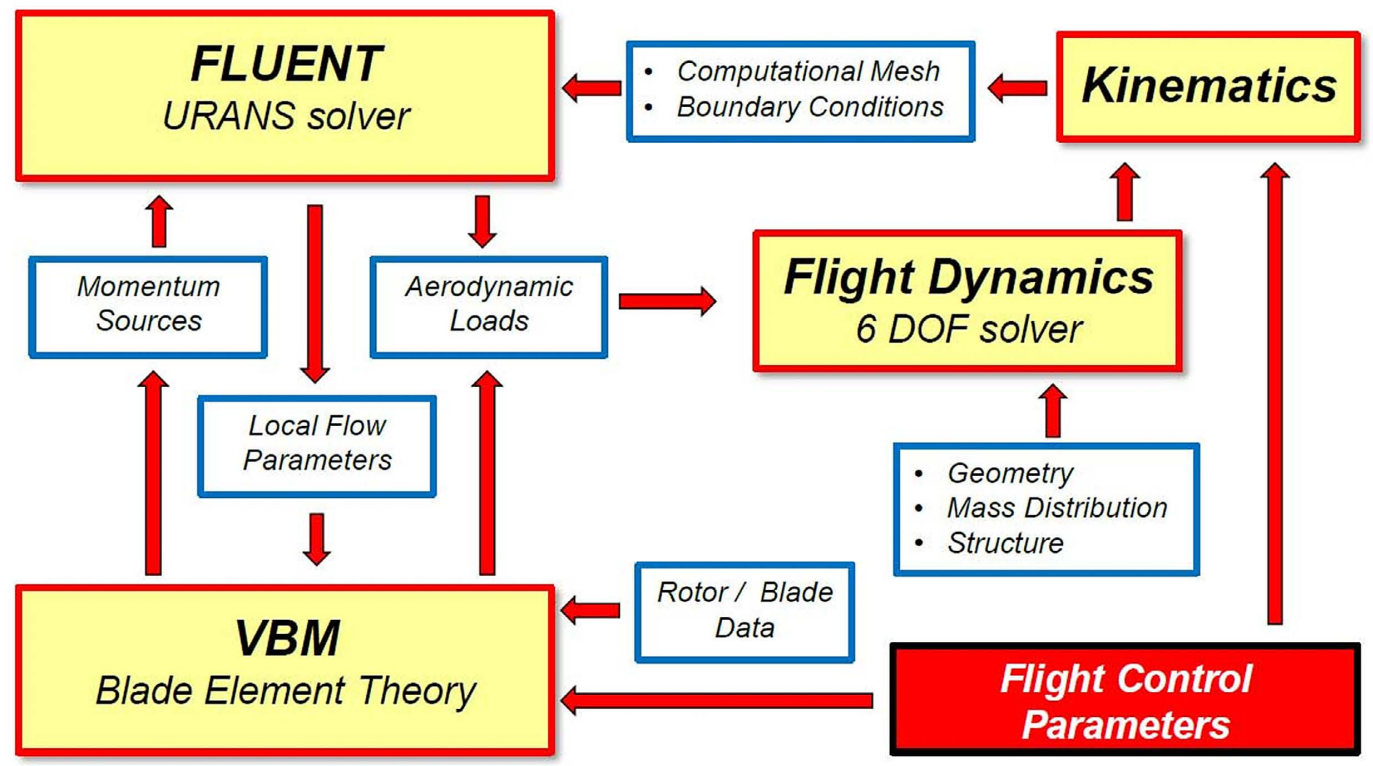

Fig. 1. General scheme of the developed methodology of rotorcraft-flight simulation [own study].

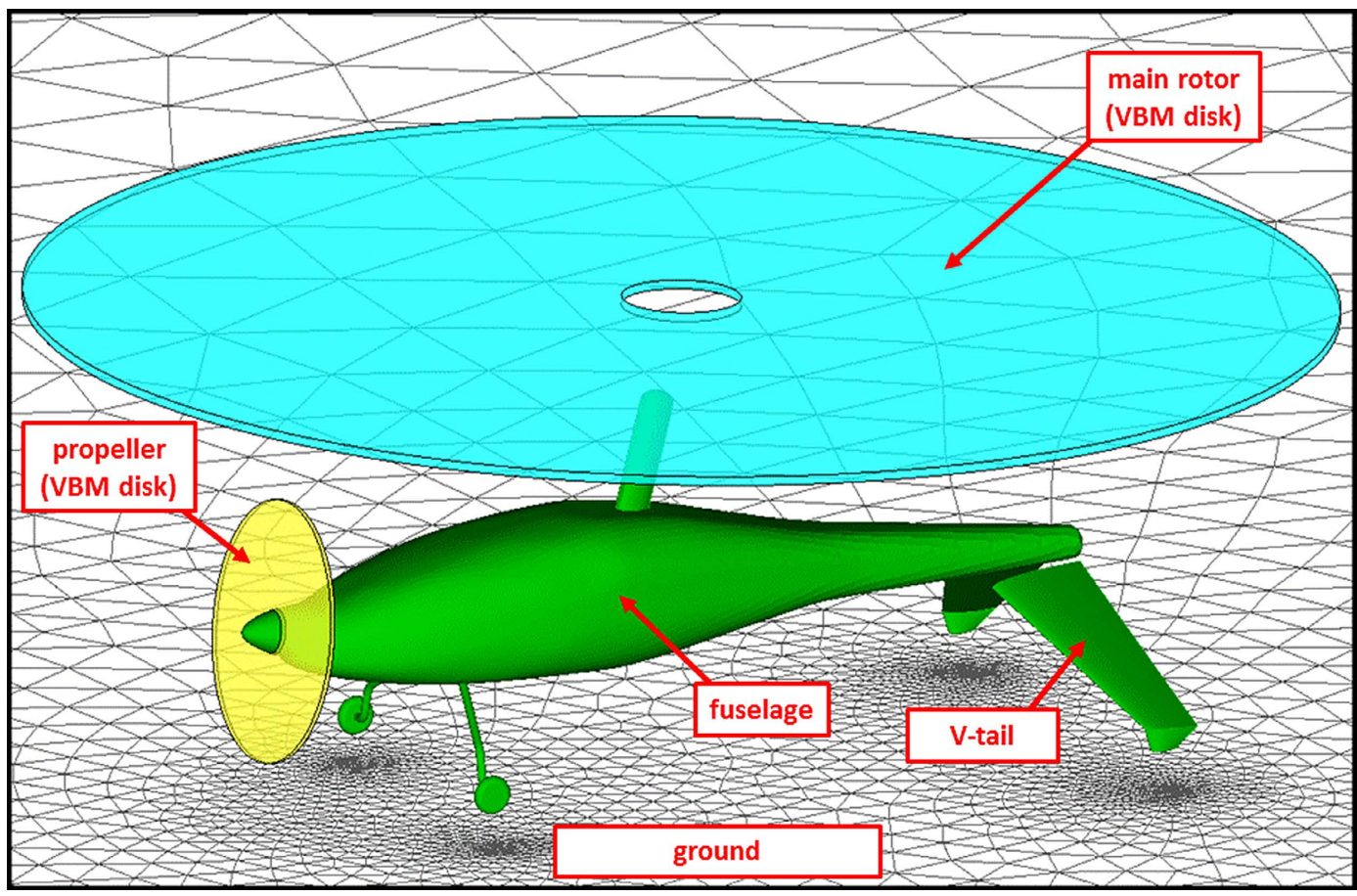

Fig. 2. Computational model of the gyroplane flying in proximity of the ground [own study]. 


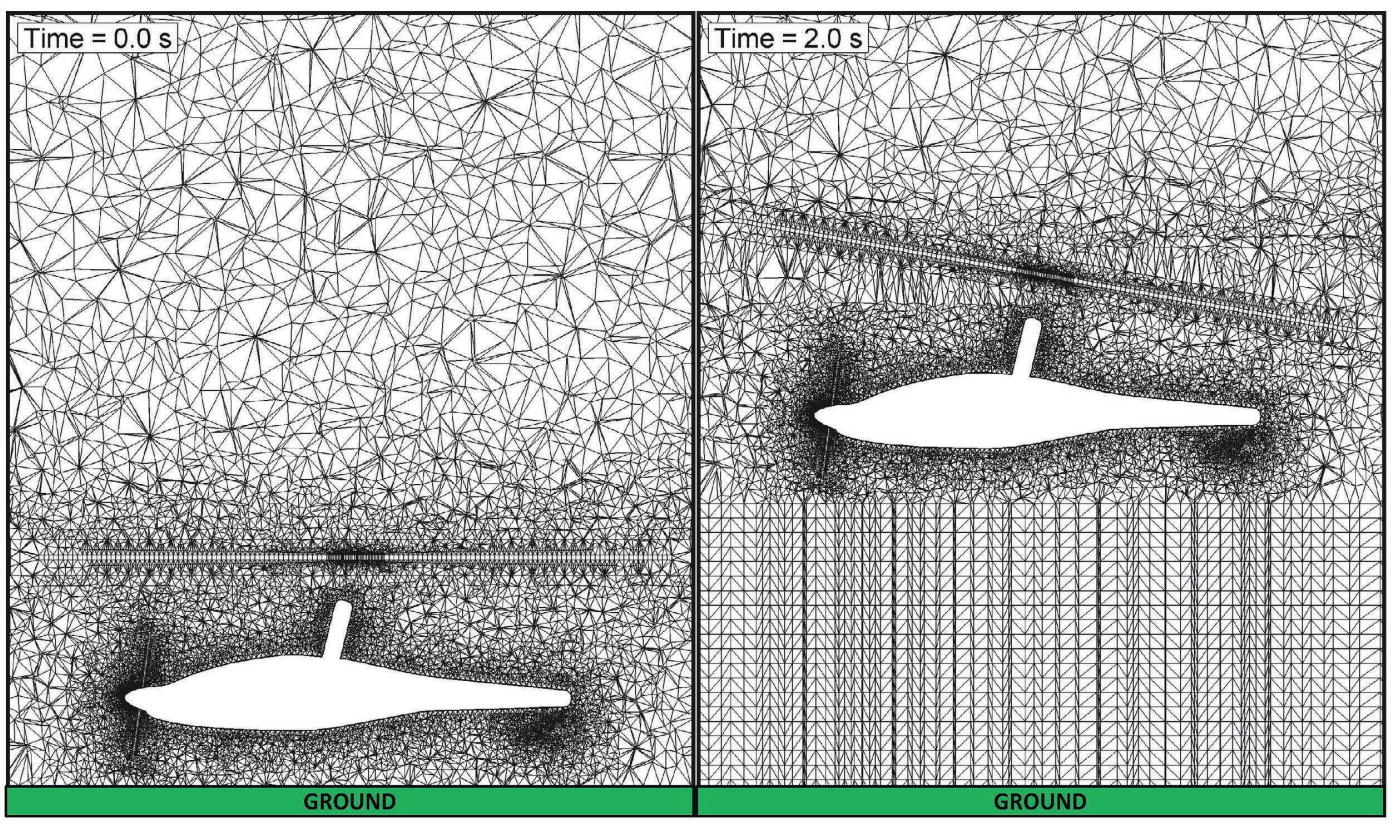

Fig. 3. Cross-section of computational mesh around the gyroplane in two different stages of flight [own study].

of real rotors. Such zones, replacing the real rotor and propeller in investigated gyroplane, are shown in Fig. 2. The momentum-source intensities are evaluated based on the Blade Element Theory which associates local flow parameters in the blade sections with databases of two-dimensional aerodynamic characteristics of blade airfoils. The original VBM code was significantly modified and expanded by the author of this paper. Beside the essential modules FLUENT and VBM, the presented methodology utilises two additional modules. The FLIGHT DYNAMIC module gathers information of all momentary loads acting on the rotorcraft and solves 6-degree-of-freedom equations of rotorcraft motion. The KINEMATICS module is responsible for modelling of effects of motion and changes of rotorcraft geometry, which is realised through redefinition of boundary conditions for the FLUENT solver and through deformations of computational mesh. The computational model of the gyroplane (Fig. 2) was developed so as to enable simulation of flight in proximity of the ground, tilting of the rotor and deflection of control surfaces. The exemplary deformations of computational mesh are presented in Fig. 3. The deformations were conducted with the use of the Dynamic Mesh technique implemented in FLUENT solver.

The described complex model of gyroplane flight was used in studies on jump start of the gyroplane where the ground effect is very important. Though the developed methodology enables to solve 6-degree-of-freedom rotorcraft flight dynamics, the jump-takeoff simulations were conducted taking into account only 3 -degree-of-freedom system, limited to force-balance equations and ignoring moment-balance equations. The rotor-optimisation studies were focused on forward flight of separate main rotor. Within this work, a new option of the VBM was developed, enabling to trim the rotor to required lift force through automatic adjustment of the rotor pitch. 


\subsection{Methodology of Design and Optimisation of Gyroplane Main Rotor and Its Blades}

The design and optimisation of the rotor and its blades were conducted based on formerly developed and implemented in-house methodology of parametric design and optimisation of aerodynamic objects [13]. The parametric model of the designed rotor and blades was developed using the specialised, in-house software PARADES [12]. The Graphical User Interface of this software is presented in Fig. 4.

The developed parametric model of rotor blade consisted of the following design parameters:

- collective pitch of rotor blades

- blade planform

- radial distribution of blade thickness

- radial distribution of blade twist
- 1 parameter

- 9 parameters

- 8 parameters

- 3 parameters

The process of optimal design of gyroplane rotor consisted in successive, manual changes of the above design parameters and analysing how those changes affect the changes of aerodynamic and performance properties of the rotor. Aerodynamic properties of subsequent variants of gyroplane main rotor were evaluated using the FLUENT and VBM codes. At that stage, the forward flight of separate main rotor was taken into consideration. During the flight simulation, the rotor pitch angle was automatically (computationally) adjusted so as to obtain required lift force generated by the rotor, balancing assumed total weight of the gyroplane. The optimisation process aimed at minimisation of drag force generated by the rotor. In this way, through successive search of the design space, the optimised/improved variants of main rotor were obtained.

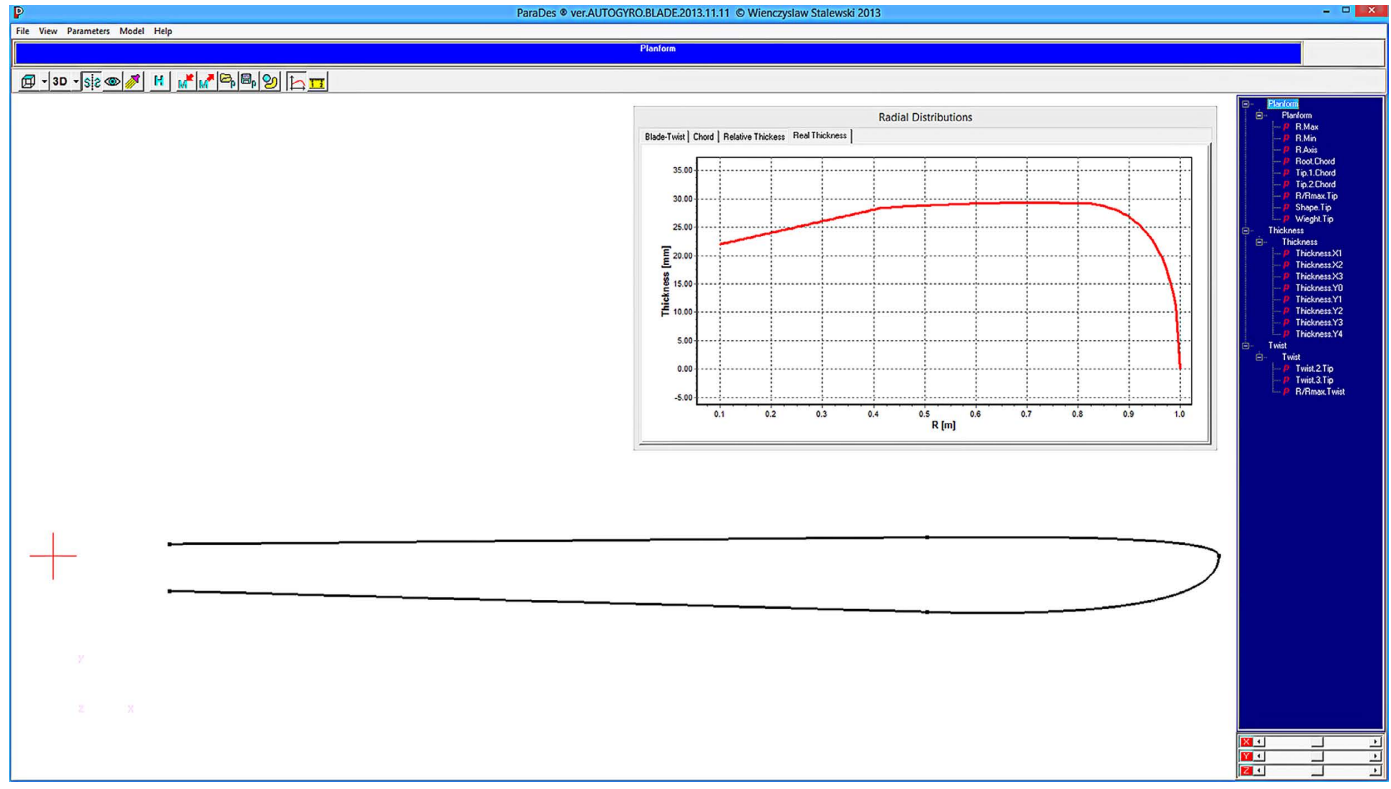

Fig. 4. Graphical User Interface of the software PARADES, used to develop the parametric model of the rotor blade [own study]. 


\section{PERFORMANCE OPTIMISATION OF GYROPLANE MAIN ROTOR IN FAST FORWARD FLIGHT}

\subsection{Design and Optimisation of Gyroplane-Airfoil Family}

The first stage of airfoil design was focused on development of airfoils dedicated for typical rectangular, untwisted blades of gyroplane rotor. The reference airfoil for the process was NACA9H12M - slightly modified version of NACA9H12 - airfoil commonly used in gyroplane applications. The actual process of airfoil design was preceded by studies aimed at defining the adequate design objectives and flow conditions typical for gyroplane-rotor flight. The studies led to the conclusion that during a fast flight of light gyroplane:

- the largest share in driving of the rotor has a retreating blade, where a quasi-2D flow is characterised by the following conditions, described by lift coefficient $\left(\mathrm{C}_{\mathrm{L}}\right)$ and Mach number $(\mathrm{M})$ :

$$
\mathrm{CL} \approx 1.2 \div 1.5, \mathrm{M} \approx 0.2 \div 0.35
$$

- the largest share in generating of harmful rotor torque has an advancing blade, where a quasi-2D flow is characterised by the following conditions:

$$
\mathrm{CL} \approx 0.2 \div 0.4, \mathrm{M} \approx 0.4 \div 0.55
$$

It was assumed that the airfoil-design process would aim at minimisation of airfoil drag coefficient, in flow conditions (1) and (2). As a result of conducted optimisation, the following three airfoils were designed: ILW-LT-12.0, ILW-LT-11.6 and ILW-LT-11.0 of relative thicknesses: $12 \%, 11.6 \%$ and $11 \%$ of airfoil chord, respectively. Selected aerodynamic characteristics $\left(\mathrm{C}_{\mathrm{L}}-\mathrm{lift}\right.$ coefficient, $\mathrm{C}_{\mathrm{D}}-$ drag coefficient, $\mathrm{C}_{\mathrm{L}} / \mathrm{C}_{\mathrm{D}}-$ aerodynamic efficiency) of the designed airfoils and the reference airfoil NACA9H12M are compared in Fig. 5, where advantages of newly-designed airfoils are visible. It especially concerns the thinnest airfoil ILW-LT-11.0 which in fast flight is better than NACA9H12M with respect to dependency $C_{L}$ vs. $C_{D}$ and maximum lift coefficient in retreatingblade conditions (1) and with respect to dependency $C_{L}$ vs. $C_{D}$ in advancing-blade conditions (2).

When developing a variable-chord blade of gyroplane rotor, it was necessary to use additional basic airfoils, thinner than ILW-LT-11.0. To meet this requirement, the following additional airfoils were designed:

- ILW-LT-10.0 of relative thickness of $10 \%$ of airfoil chord

- ILW-LT-09.0 of relative thickness of $9 \%$ of airfoil chord

Finally, the sub-family of gyroplane airfoils intended for the variable-chord blade consisted of the airfoils: ILW-LT-9.0, ILW-LT-10.0 and ILW-LT-11.0. Aerodynamic characteristics of the airfoils as well as the reference airfoil NACA9H12M are compared in Fig. 6. It can be concluded that in assumed flow conditions (1) and (2), the airfoils in comparison to the reference airfoil have improved aerodynamic characteristics.

All the newly-designed airfoils indicate a pitching moment coefficient $\mathrm{C}_{\mathrm{m}}$ similar as the reference airfoil (NACA9H12M) and maximum lift coefficient $\left(\mathrm{C}_{\mathrm{Lmax}}\right)$ in the retreating-blade conditions (1) higher than reference airfoil, which was achieved during the airfoil-optimisation process through adequate definition of optimisation constraints. 
$M=0.3, \operatorname{Re}=1500000$

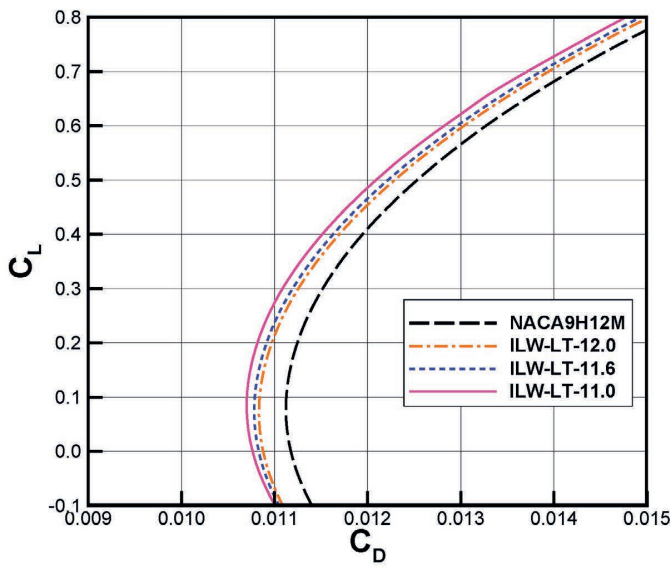

$M=0.5, R e=2600000$

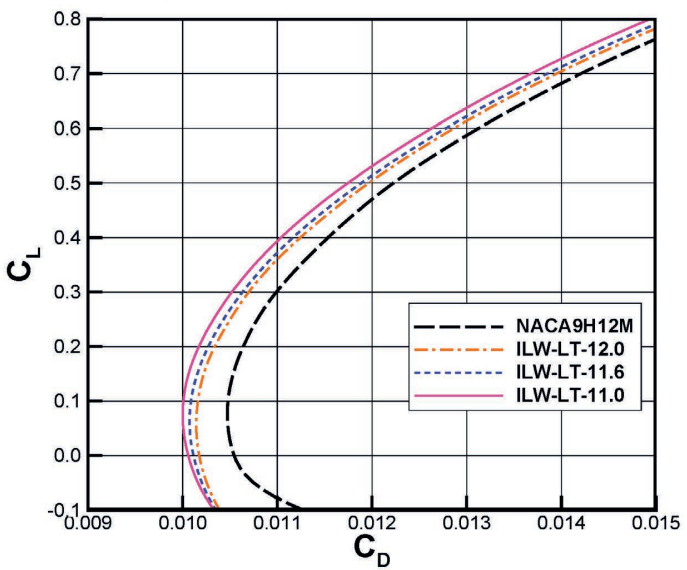

$M=0.3, \operatorname{Re}=1500000$

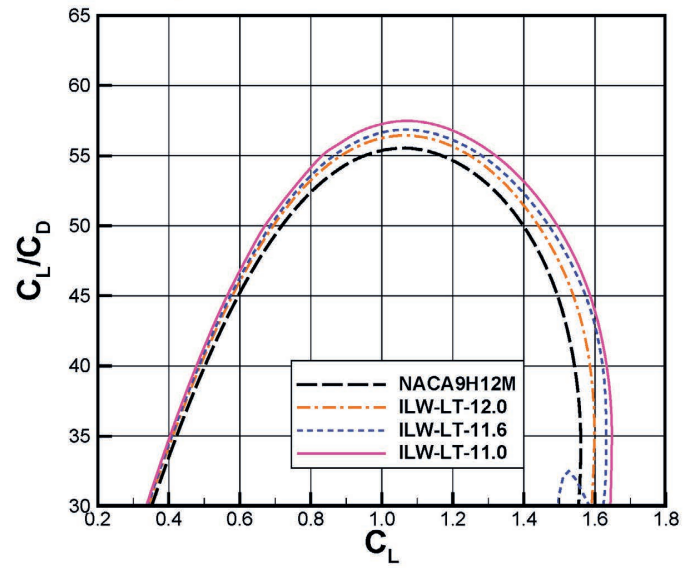

$M=0.5, \operatorname{Re}=2600000$

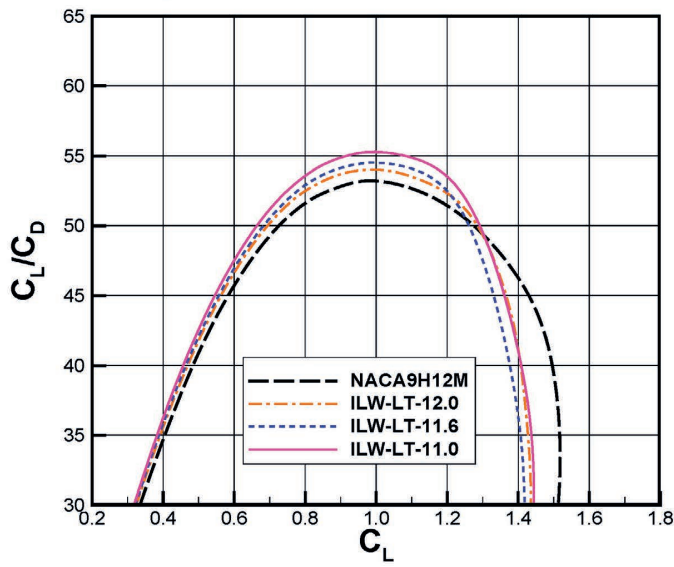

Fig. 5. Comparison of aerodynamic characteristics of airfoils ILW-LT-12.0, ILW-LT-11.6, ILW-LT-11.0 and NACA9H12M, for flight conditions $\mathrm{M}=0.3, \mathrm{Re}=1.5 \cdot 10^{6}$ and $\mathrm{M}=0.5, \mathrm{Re}=2.6 \cdot 10^{6}$. Results of calculations conducted using the ANSYS FLUENT solver [own study].

\subsection{Design of Gyroplane Main Rotor with Rectangular Blades}

Blades of the first optimised rotor were to be made of aluminium alloy, which forced simple blade design, characterised by uniform spanwise distribution of the blade section (airfoil) and chord. The process of rotor optimisation consisted in optimal choice of the blade airfoil and dimensions as well as optimisation of fixed collective pitch of rotor blades. The eventual choice from three newly designed airfoils: ILW-LT-12.0, ILW-LT-11.6 and ILW-LT-11.0. was based on the results of rotor-flight simulations conducted for flight speed $160 \mathrm{~km} / \mathrm{h}$ and total mass of gyroplane $600 \mathrm{~kg}$. Fig. 7 compares rotor Lift-to-Drag ratio (L/D) versus blade collective pitch $\left(\theta_{0}\right)$ evaluated for gyroplane rotors equipped with rectangular blades built based on three new airfoils as well as based on reference airfoil NACA9H12M. Eventually, the airfoil ILW-LT-11.0 was selected, due to the highest aerodynamic efficiency of the rotor associated with this airfoil. In further steps, dimensions of rectangular blade 
$M=0.3, \operatorname{Re}=1500000$

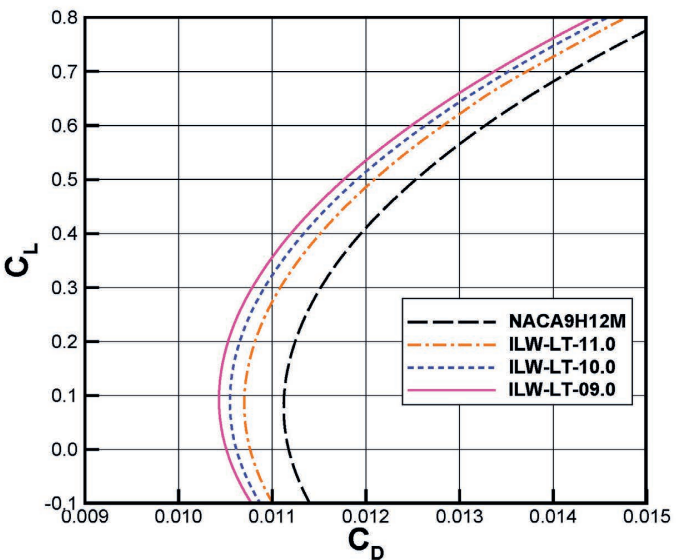

$M=0.5, R e=2600000$

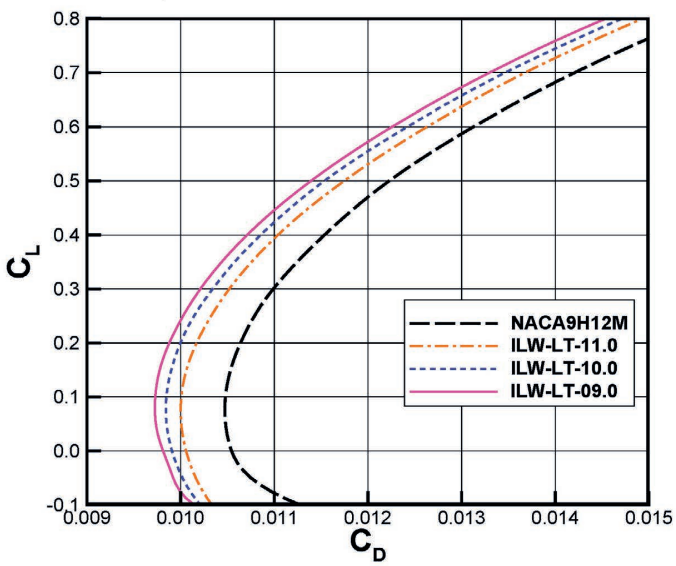

$M=0.3, R e=1500000$

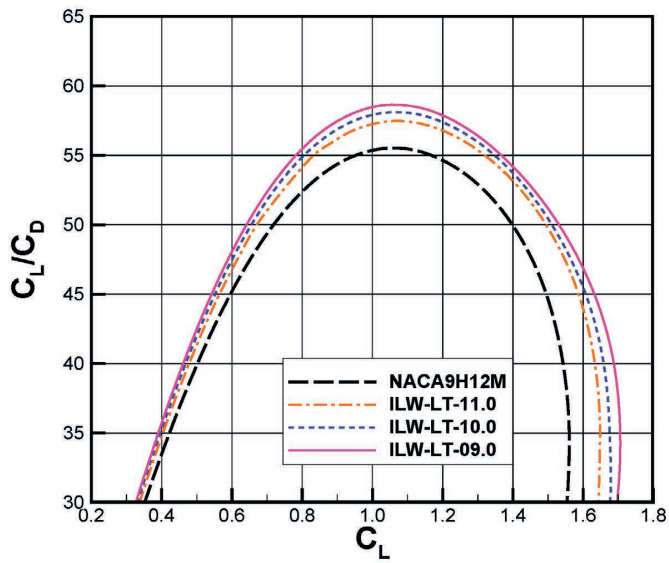

$M=0.5, \operatorname{Re}=2600000$

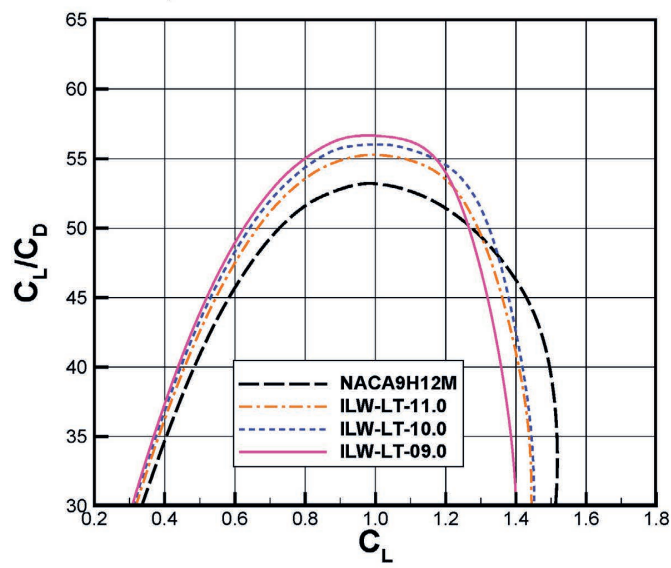

Fig. 6. Comparison of aerodynamic characteristics of airfoils ILW-LT-09.0, ILW-LT-10.0, ILW-LT-11.0 and NACA9H12M, for flight conditions $M=0.3, R e=1.5 \cdot 10^{6}$ and $M=0.5, R e=2.6 \cdot 10^{6}$. Results of calculations conducted using the ANSYS FLUENT solver [own study].

were optimised through analysis of several combinations of blade radius and chord. Finally, the rotor of diameter $10 \mathrm{~m}$, blade chord $0.22 \mathrm{~m}$ and blade airfoil ILW-LT-11.0 was established as the final design and named ILW.11/11/11.D10.0. Optimum collective pitch of blades of this rotor is $5 \mathrm{deg}$.

Good performance properties of the rotor ILW.11/11/11.D10.0 have been proven during flight tests [11], where two alternative main rotors were mounted and tested on the same gyroplane. The first was the optimised rotor ILW.11/11/11.D10.0 while the second, reference rotor had the same blade planform but blade airfoil NACA9H12M. During the flights the gyroplane equipped with the optimised rotor reached higher by $20 \mathrm{~km} / \mathrm{h}$ (approx. 10\%) maximum flight speed in comparison to the gyroplane with the reference rotor. During majority of flights, the time of classic take-off of the gyroplane with the optimised rotor was shorter by approximately $10 \mathrm{sec}$. It is worth mentioning that the newly designed duralumin rotor also gained full commercial use - so far almost 50 such rotors were sold to 16 countries [9]. 


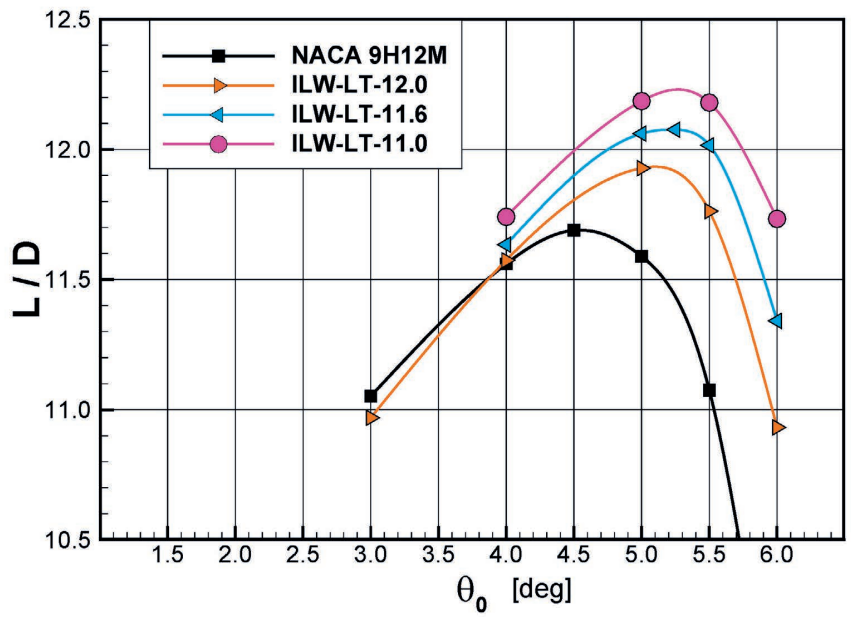

Fig. 7. Lift-to-Drag ratio (L/D) versus collective pitch $\left(\theta_{0}\right)$ in fast flight of main rotors equipped with rectangular blades built based on airfoils: ILW-LT-12.0, ILW-LT-11.6, ILW-LT-11.0 and airfoil NACA9H12M. Flight velocity: $160 \mathrm{~km} / \mathrm{h}$, total mass: $600 \mathrm{~kg}$ [own study].

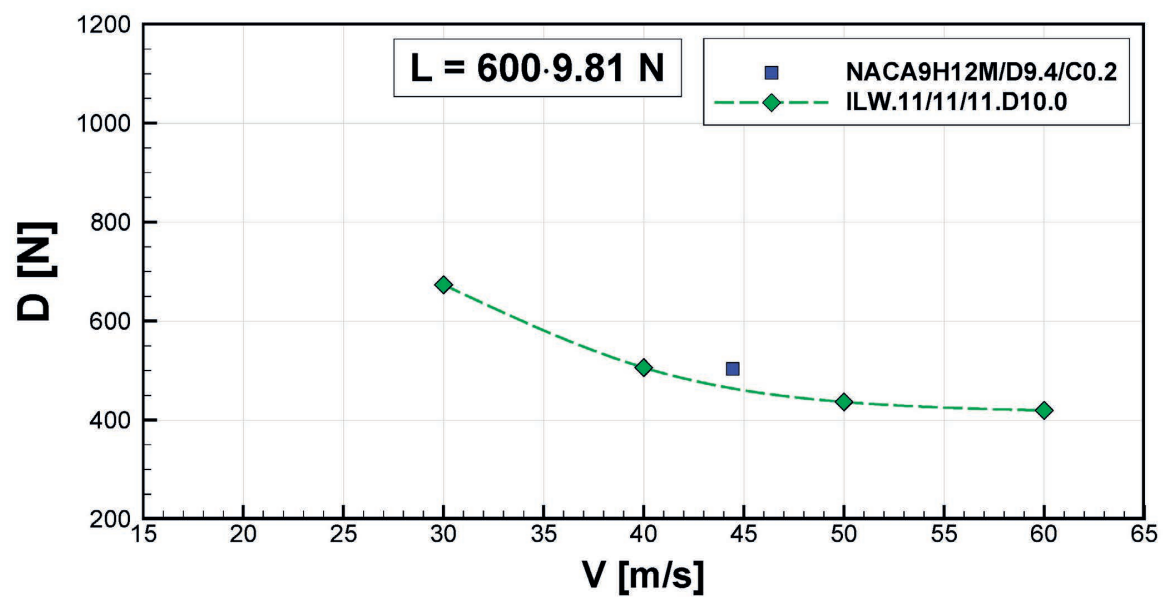

Fig. 8. Total drag force generated by the rotor (D) vs. flight velocity (V). Results of simulations of flight of the gyroplane equipped with two alternative rotors: ILW.11/11/11.D10.0 and NACA9H12M/D9.4/C0.2 [own study].

\subsection{Design of Gyroplane Main Rotor with Variable-Chord Blades}

The blades of the second designed gyroplane main rotor were to be made in composite technology, which allowed to extend the scope of the design parameters. In particular, the parametric model of the rotor blade allowed to introduce span-variable distributions of the blade chord, twist and airfoils (blade sections). In this case, the design process consisted in searching for optimal values of design parameters describing the above geometric properties of the blade. As a result of this process, the rotor ILW.11/10/09.D10.0 was developed. Its blade planform is presented in Fig. 9. The blade based on 


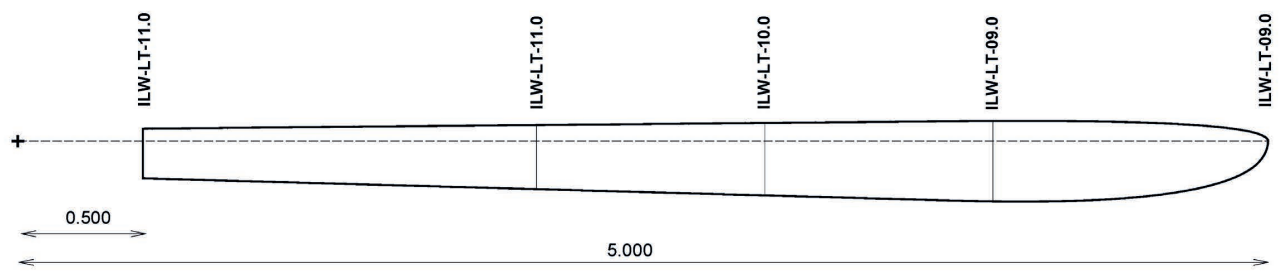

Fig. 9. The planform of the variable-chord blade of the rotor ILW.11/10/09.D10.0 [own study].

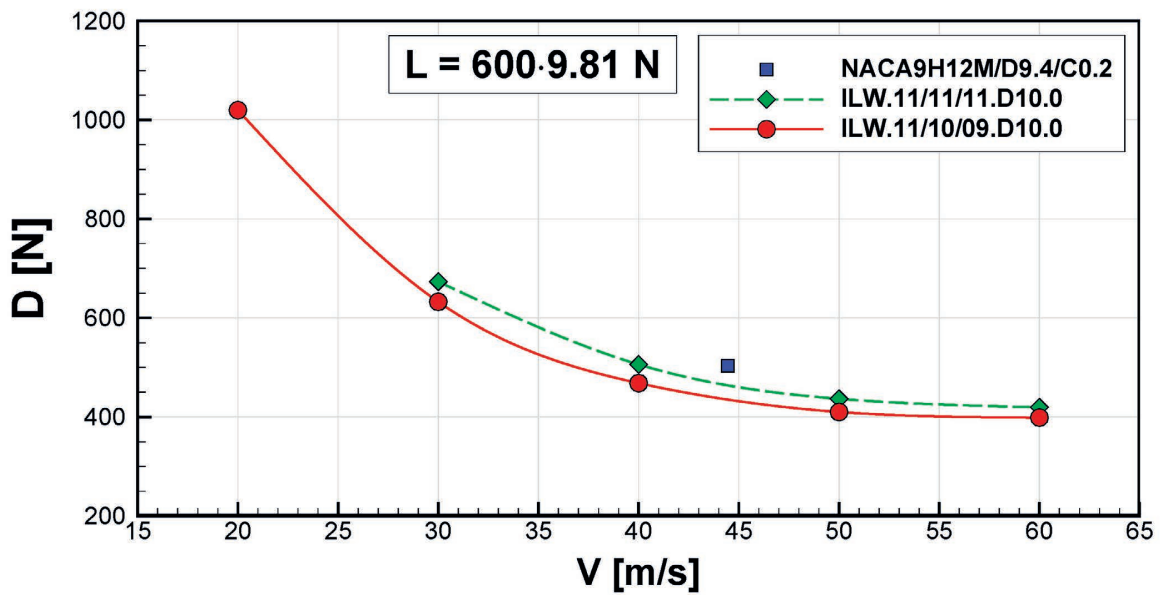

Fig. 10. Total drag force (D) acting on the rotor versus flight velocity (V), during the flight of the gyroplane of total mass $600 \mathrm{~kg}$. Comparison of computational results for the reference rotor NACA9H12M/D9.4/C0.2 and for the newly designed and optimised rotors ILW.11/11/11.D10.0 and ILW.11/10/09.D10.0 [own study].

airfoils ILW-LT-11.0, ILW-LT-10.0 and ILW-LT-09.0 and it has an unconventional planform, with the maximum chord placed at $80 \%$ of the blade radius. The blade is not twisted. In a gyroplane fast flight, the optimum blade collective pitch is $5 \mathrm{deg}$.

Fig. 10 presents dependency of rotor drag force versus flight velocity, in flight of the gyroplane of total mass $600 \mathrm{~kg}$. The presented computational results concern the optimised rotors ILW.11/11/11. D10.0 and ILW.11/11/11.D10.0 as well as the reference rotor NACA9H12M/D9.4/C0.2. It can be concluded that for the flight speed $160 \mathrm{~km} / \mathrm{h}$ the newly designed rotor ILW.11/10/09.D10.0 is characterised by $13.8 \%$ reduction in drag force in comparison to the reference rotor.

\section{PERFORMANCE OPTIMISATION OF LIGHT GYROPLANE DURING JUMP TAKEOFF}

The optimisation of light-gyroplane performance during the jump takeoff was conducted in the case of the gyroplane shown in Figure 2 equipped with the main rotor ILW.11/10/09.D9.4 which was similar to the rotor ILW.11/10/09.D10.0, but due to technical limitations, its diameter was reduced to $9.4 \mathrm{~m}$, which is shown in Fig. 11. 


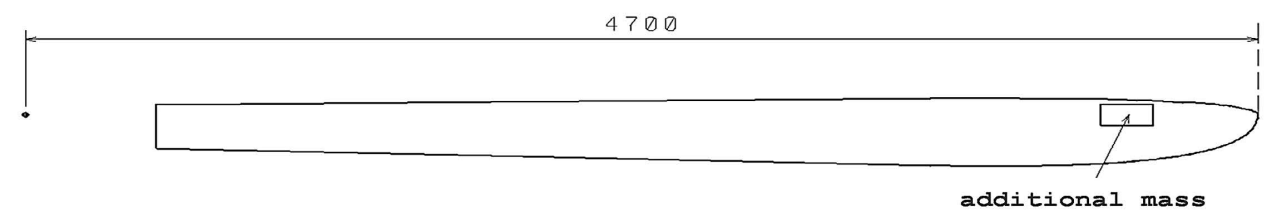

Fig. 11. The planform of the variable-chord blade of the rotor ILW.11/10/09.D9.4 being a subject of studies on performance optimisation in jump takeoff.

CFD simulations of jump takeoff of the light gyroplane were conducted on the basis of the previously described methodology. Basic conditions of the conducted simulations are presented in Tab. 1

Tab. 1 Flight conditions defined for simulations of gyroplane jump takeoff

\begin{tabular}{|l|l|}
\hline takeoff mass of the gyroplane & $600 \mathrm{~kg}$ \\
\hline maximum static thrust of the propeller & $3100 \mathrm{~N}$ \\
\hline rotational speed of the propeller & $282.6 \mathrm{rad} / \mathrm{s}$ \\
\hline
\end{tabular}

\subsection{Studies on Influence of Rotor Moment of Inertia on the Jump-Start Performance}

Based on practice of gyroplane exploitation it is known that an increase of moment of inertia of the main rotor may advantageously affect the efficiency of jump takeoff [6]. Therefore, in the conducted investigation several mass models of the blades were taken into consideration. In the paper two of such models are discussed:

- "nominal-moment-of-inertia"

- "increased-moment-of-inertia"

The later configuration assumes the installation inside the blade tip the cuboid piece of lead, as shown in Figure 11, which significantly increases the moment of inertia of the rotor (approximately up to $40 \%$ in comparison to the "nominal" configuration). Conduction of simulations of jump-takeoff of the gyroplane required determination of the initial state of the flow, which was obtained by solution of steady RANS equations describing the flow around the gyroplane during an on-ground, rotor-pre-rotation phase - necessary to perform jump takeoff. In this state, the following control parameters, defined in Tab. 2, were assumed:

Tab. 2 Control parameters assumed during the on-ground, rotor-pre-rotation phase

\begin{tabular}{|l|l|l|}
\hline rotor rotational speed in pre-rotation & $\Omega_{\mathrm{R}}$ & $50.7 \mathrm{rad} / \mathrm{s}$ \\
\hline collective pitch of rotor blades & $\theta_{0}$ & $0 \mathrm{deg}$ \\
\hline collective pitch of propeller blades & $\theta_{\mathrm{P}}$ & $12 \mathrm{deg}$ \\
\hline rotor-pitch angle & $\varphi_{\mathrm{R}}$ & $0 \mathrm{deg}$ \\
\hline
\end{tabular}


The initial state of the flow around the gyroplane during the rotor-pre-rotation phase is presented in Fig. 12. Starting from this state, the unsteady simulation of gyroplane jump takeoff was conducted. During this manoeuvre, the strategy of changes of control parameters, $\varphi_{R}, \theta_{0}, \theta_{P}$ was assumed in a manner shown in Fig. 13.

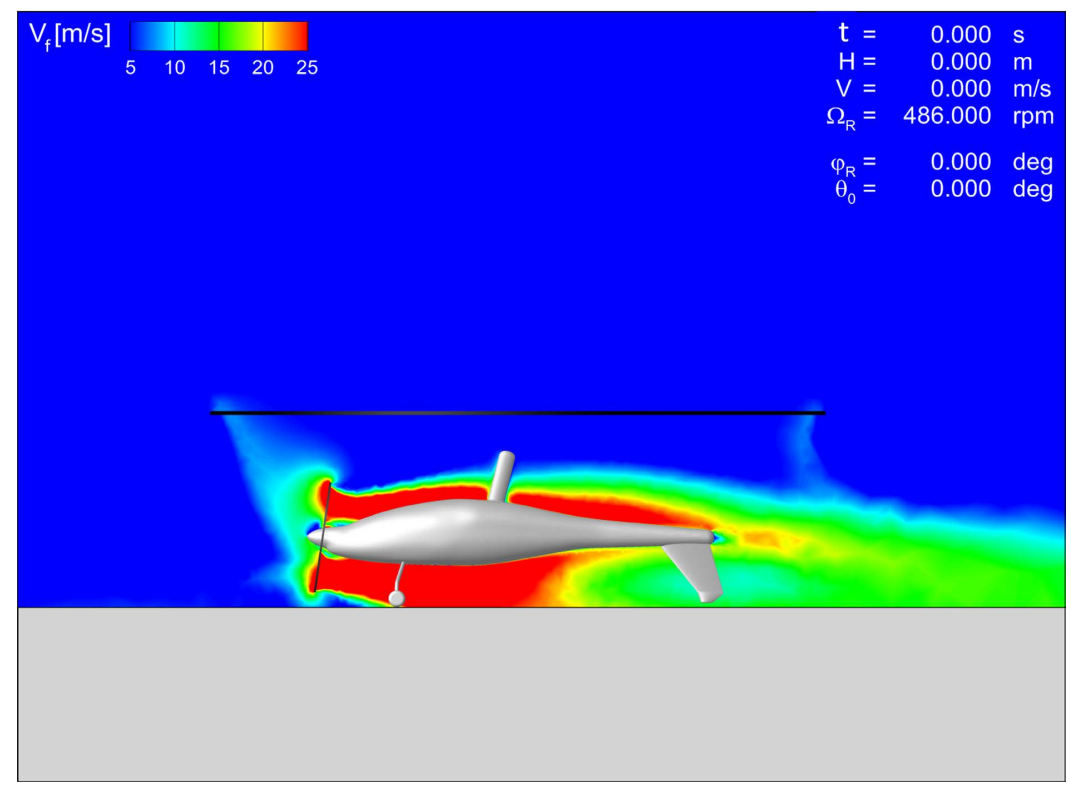

Fig. 12. Initial state of the flow around the gyroplane during the rotor-pre-rotation phase [own study].

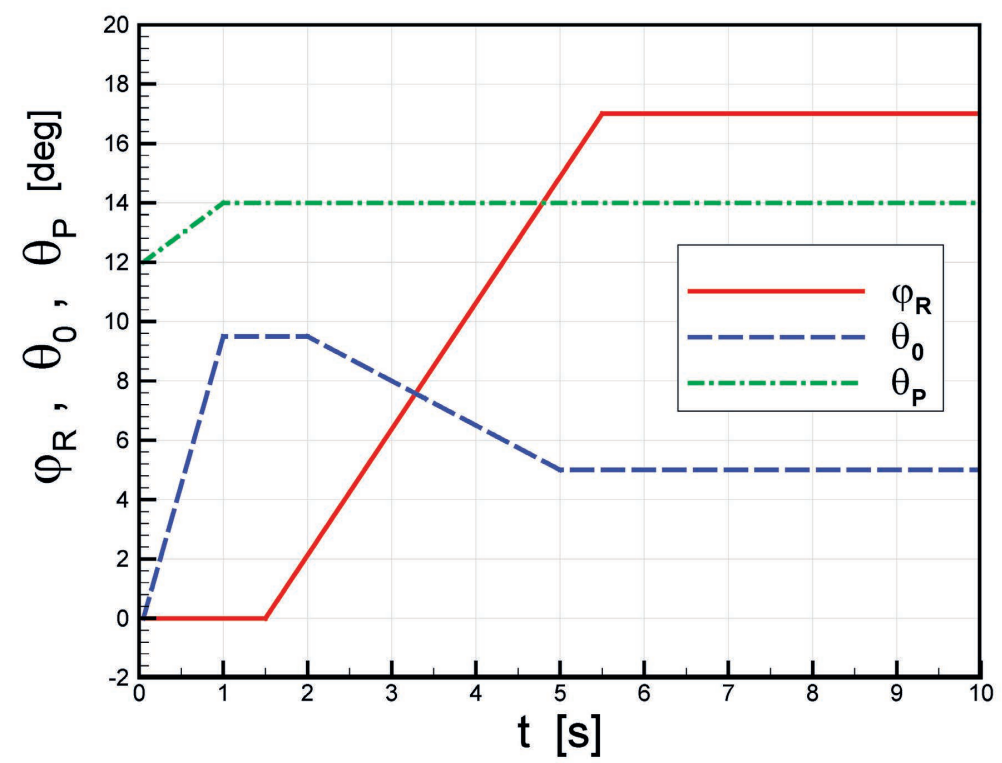

Fig. 13. The initial strategy of changes of flight-control parameters during the jump takeoff of the gyroplane [own study]. 


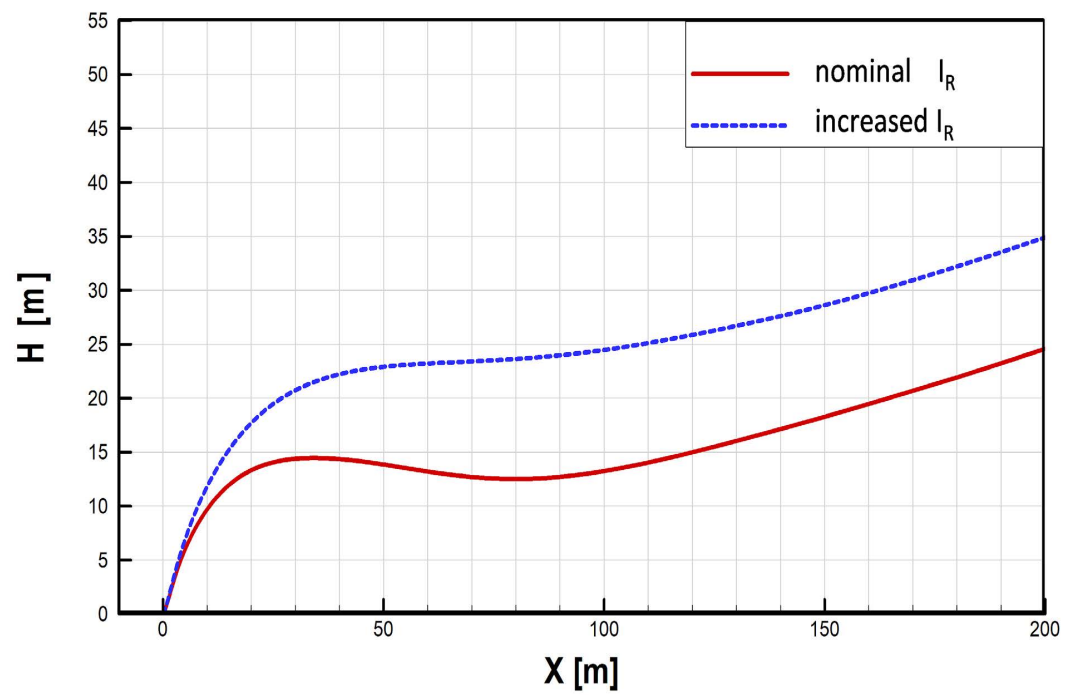

Fig. 14. Comparison of gyroplane trajectories during the jump takeoff for two configurations: nominal and increased moment of inertia of the rotor $\left(I_{R}\right)$. Flight altitude $(H)$ vs. travelled distance $(X)$ [own study].

The angles of rotor pitch $\left(\theta_{R}\right)$ and collective pitch of rotor blades $\left(\theta_{0}\right)$ were used directly to control the flight of the gyroplane while changes of collective pitch of propeller blades $\left(\theta_{\mathrm{p}}\right)$ were used to simulate changes of thrust of the propeller. The strategy presented in Fig. 13 was developed based on series of simulations, where various values of flight-control parameters were established manually. In the next sub-section, the numerical optimisation of flight-control parameters is presented. Figure 14 compares trajectories of the gyroplane during the jump takeoff for two configurations corresponding to the nominal and the increased moment of inertia of gyroplane rotor $\left(I_{R}\right)$. The figure shows the dependence of flight altitude $(\mathrm{H})$ versus distance travelled by the gyroplane $(\mathrm{X})$. As expected, it was found that the increase in the rotor moment of inertia can significantly improve the efficiency of jump takeoff, in this case measured by the altitude reached by the gyroplane after rapid-ascent phase. Fig. 15 presents snapshots of flow field around the gyroplane taken during the jump-takeoff simulation at time moments $\mathrm{t}=1,3$ and $6.5 \mathrm{sec}$, for two compared configurations of the gyroplane main rotor.

\subsection{Optimisation of the Gyroplane-Flight-Control Strategy During the Jump Takeoff}

Improvement of gyroplane-flight-control strategy during the jump takeoff was conducted based on numerical optimisation approach. Assumed basic flight-control parameters were:

- pitch angle of main rotor $\left(\varphi_{\mathrm{R}}\right)$

- collective pitch of rotor blades $\left(\theta_{0}\right)$

Time-variable functions, defining changes of the flight-control parameters during the jump takeoff, were assumed in a form presented in Figure 16 where:

- function $\varphi_{\mathrm{R}}=\varphi_{\mathrm{R}}(\mathrm{t})$ is unambiguously defined by unknown parameters: $\mathrm{D}_{1}, \mathrm{D}_{2}, \mathrm{~F}_{1}$

- function $\theta_{0}=\theta_{0}(t)$ is unambiguously defined by unknown parameters: $D_{3}, D_{4}, F_{2}, F_{3}$ 


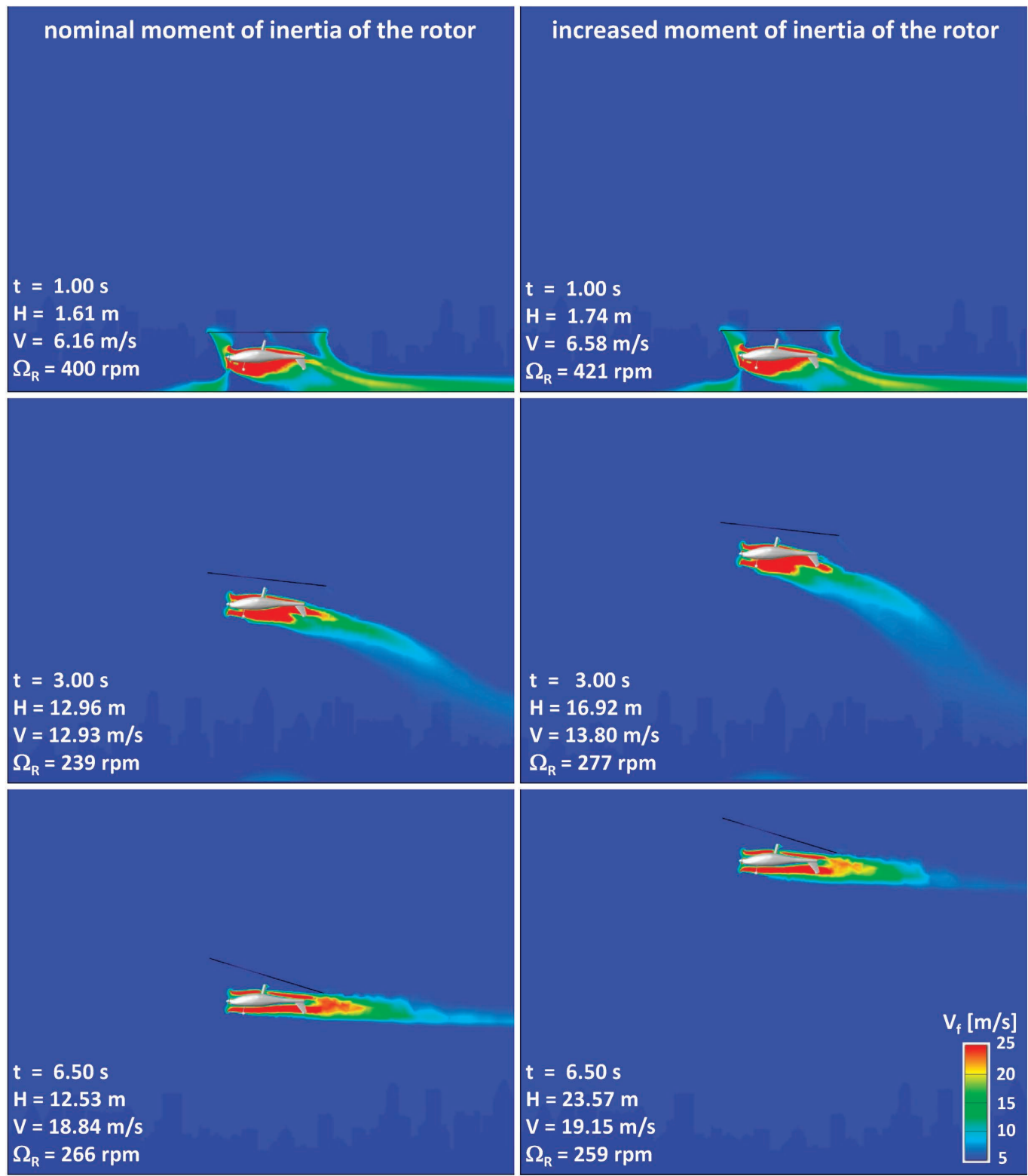

Fig. 15. Comparison of velocity-magnitude contours around the gyroplane in jump-takeoff phase, for two configurations of gyroplane rotor: "nominal moment of inertia" (left) and "increased moment of inertia “ (right). Selected time moments of gyroplane jump takeoff:

$\mathrm{t}=1,3$ and $6.5 \mathrm{sec}$ [own study].

The optimisation problem consisted in determination of optimal values of unknown parameters $\mathrm{D}_{1}, \mathrm{D}_{2}, \mathrm{D}_{3}, \mathrm{D}_{4}, \mathrm{~F}_{1}, \mathrm{~F}_{2}$ and $\mathrm{F}_{3}$. The assumed optimisation objective was the altitude reached by the gyroplane after traveling the distance of $100 \mathrm{~m}$ from the takeoff place (see Fig. 17). The objective should have been maximised. The optimisation problem was finally expressed in mathematical terms 
as searching for the set of parameters $\mathrm{D}_{1}, \mathrm{D}_{2}, \mathrm{D}_{3}, \mathrm{D}_{4}, \mathrm{~F}_{1}, \mathrm{~F}_{2}, \mathrm{~F}_{3}$ maximising the following objective function $\Psi$ :

$$
\Psi\left(\mathrm{D}_{1}, \mathrm{D}_{2}, \mathrm{D}_{3}, \mathrm{D}_{4}, \mathrm{~F}_{1}, \mathrm{~F}_{2}, \mathrm{~F}_{3}\right)=\mathrm{H}(\mathrm{X}=100 \mathrm{~m})
$$

The optimisation was conducted under the following constraints:

$$
\begin{aligned}
& \mathrm{D}_{1} \geq 0, \mathrm{D}_{2} \geq 1, \mathrm{D}_{3} \geq 0, \mathrm{D}_{4} \geq 1 \\
& \left|\mathrm{~F}_{1} / \mathrm{D}_{2}\right| \leq \lambda_{1} \\
& \left|\left(\mathrm{~F}_{2}-\mathrm{F}_{3}\right) / \mathrm{D}_{4}\right| \leq \lambda_{2}
\end{aligned}
$$

where $\lambda_{1}, \lambda_{2}$ are assumed limits of angular speed of changes of $\varphi_{R}$ and $\theta_{0}$ respectively. The optimisation problem $(3)+(4)+(5)+(6)$ has been solved by application of appropriately adapted optimisation method BFGS [10]. At every step of iterative process of optimisation, the necessary gradients of the objective (3) were approximated using the finite-difference method, which needed to conduct several independent simulations of gyroplane jump takeoff for different values of parameters $\mathrm{D}_{1}, \mathrm{D}_{2}, \mathrm{D}_{3}, \mathrm{D}_{4}, \mathrm{~F}_{1}, \mathrm{~F}_{2}, \mathrm{~F}_{3}$. The initial flight-control strategy was assumed in the form presented Fig. 13. The optimisation process consisted in gradual improvement of this strategy, so as to increase the objective (3). The final solution of the optimisation is presented in Fig. 18. The optimised flight-control strategy is characterised by nearly the same values of parameters $\mathrm{F}_{2}$ and $\mathrm{F}_{3}$, which means that the phase of decreasing of the rotor pitch (see Fig. 16) can be omitted. Fig. 19 compares gyroplane-flight trajectories during the jump takeoff for two gyroplane-flight-control strategies: initial (Fig. 13) and optimised (Fig. 18). It can concluded that optimised trajectory is growing monotonically while the initial trajectory has a local minimum. For the optimised flight-control strategy the objective (3) is higher by approximately $5 \mathrm{~m}$ than for the initial strategy.

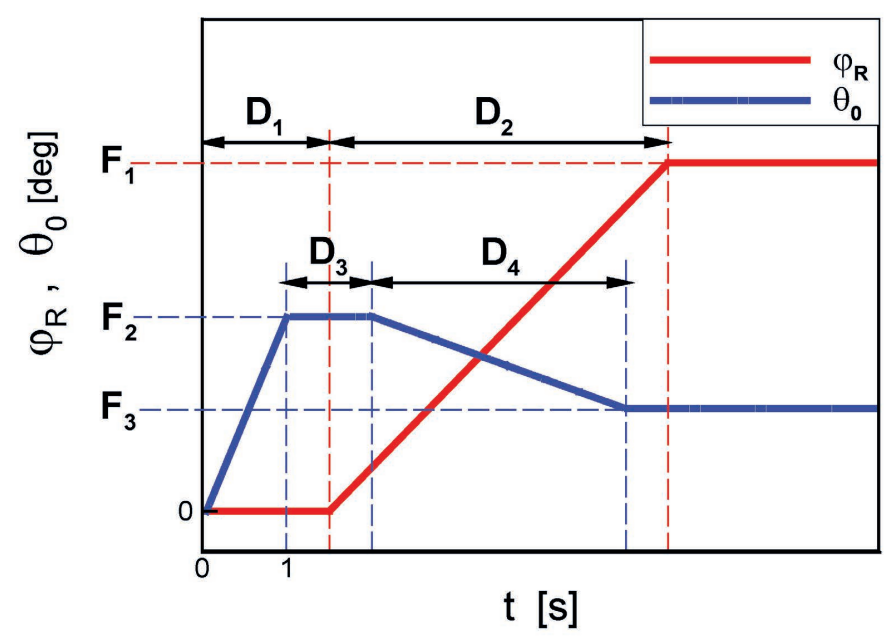

Fig. 16. Parametric model of the gyroplane-flight-control strategy utilised in the optimisation process [own study]. 


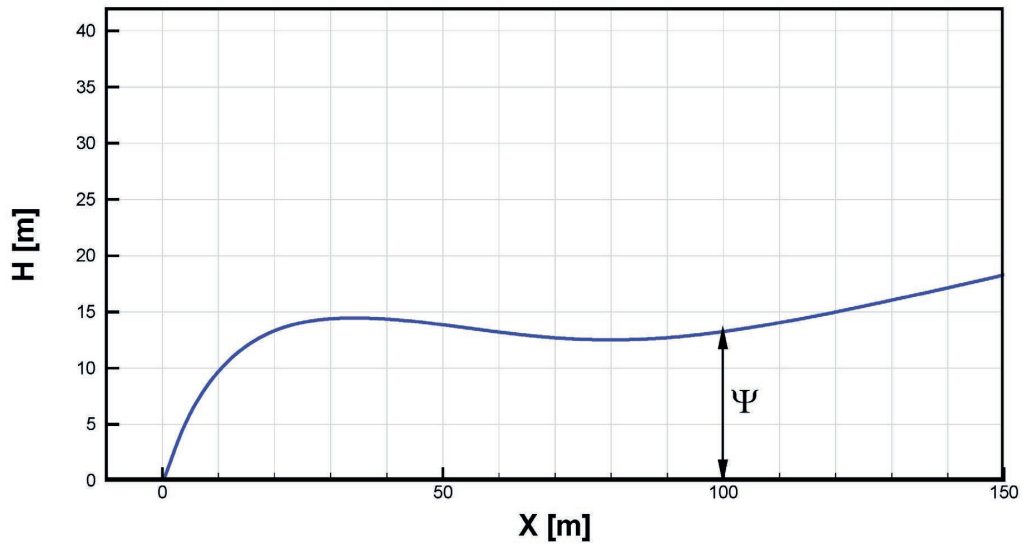

Fig. 17. Definition of the objective $(\Psi)$ for the optimisation of jump-takeoff-control strategy [own study].

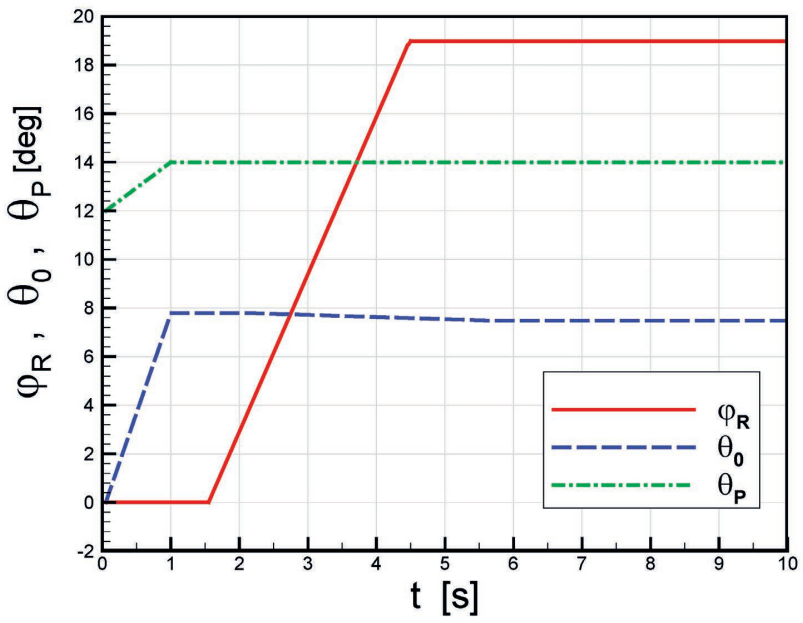

Fig. 18. Solution of the optimisation problem: the optimised gyroplane-flight-control strategy [own study].

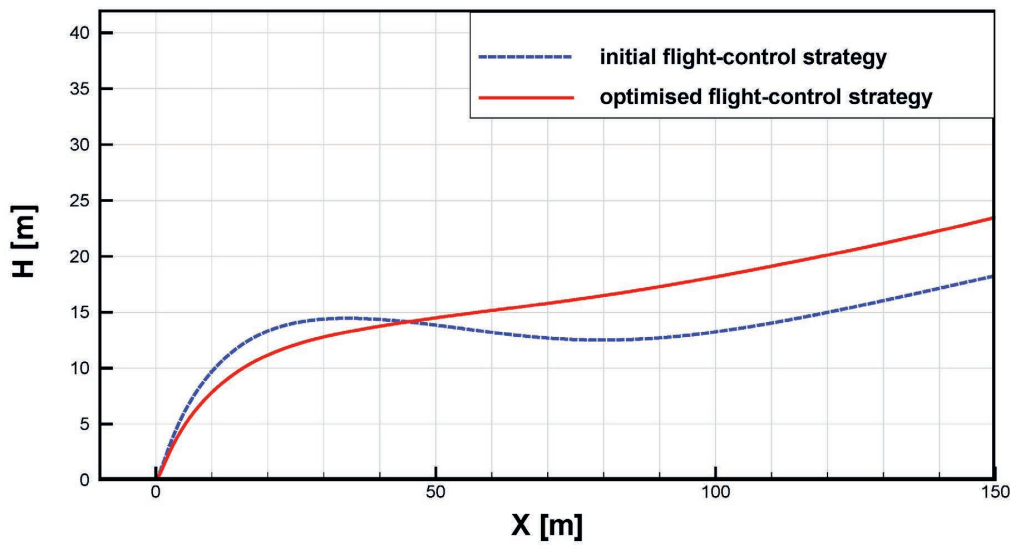

Fig. 19. Gyroplane trajectories during the jump takeoff for two flight-control strategies: initial (see Fig. 13) and optimised (see Fig. 18). The dependence of flight altitude $(\mathrm{H})$ vs. travelled distance (X) [own study]. 


\section{CONCLUSIONS}

The results of the presented study confirm that based on modern CAD, CFD, Flight Dynamics and Engineering Optimisation methods it is possible to improve performance of light gyroplane. The improvement can be achieved both through the optimisation of gyroplane design and through optimisation of gyroplane-flight control.

In a fast cruise flight, the improvement of performance was achieved through optimisation of gyroplane main rotor. Two alternative rotors were designed. Their blades were built on the basis of a family of optimised airfoils. Blades of the first optimised rotor have a rectangular planform, while the second rotor has blades of span-variable chord and thickness. In a gyroplane fast flight, the optimised rotors are characterised by respectively $7.5 \%$ and $13.8 \%$ reduction in drag force, compared to the reference rotor. A good performance of the optimised rotor of rectangular blades was proven during flight tests of a real gyroplane.

Concerning the jump-takeoff, the gyroplane-performance improvement was achieved by optimising the moment of inertia of the rotor as well as by a numerical optimisation of flight-control strategy. Optimisation of the rotor moment of inertia caused that at the distance of $100 \mathrm{~m}$ from a takeoff point, the gyroplane with an optimised rotor, reached the altitude higher by approximately $11.2 \mathrm{~m}$ than the gyroplane with the reference rotor. The numerical optimisation of flight-control strategy caused that gyroplane controlled according to the optimised strategy reached the altitude higher by $5 \mathrm{~m}$ altitude than the reference gyroplane.

\section{ACKNOWLEDGMENTS}

The research leading to these results was co-financed by the European Regional Development Fund under the Operational Programme Innovative Economy 2007-2013, within the project "Modern Gyroplane Main Rotor".

\section{BIBLIOGRAPHY}

[1] ANSYS Inc., “ANSYS FLUENT User's Guide. Release 14.5”, 2013, available at: http://www.ansys.com

[2] Capon, P. T., 1979, Cierva's First Autogiros, Aeroplane Monthly, Vol. 7 No. 4, May 1979, pp. 234-240.

[3] Cieślak S., 2011, Analiza możliwości zwiększenia prędkości przelotowej i zmniejszenia poziomu hałasu wiatrakowca ("Analysis of the possibility of increasing cruise speed and reduce autogiro's noise”), Prace Instytutu Lotnictwa, Nr 219. s. 31-38. (in Polish)

[4] Cieślak S., 2011, Analiza wpływu czynników konstrukcyjnych oraz parametrów sterowania na czas trwania i wysokość bezrozbiegowego startu wiatrakowca ("Analysis of the impact of design factors and control parameters on duration and height of autogiro's jump start"),. Prace Instytutu Lotnictwa, Nr 219. s. 39-46. (in Polish)

[5] Drela M., Youngren H., Scherrer M., and Deperrois A., 2012, "XFLR-5”, available at: http://www.xflr5.com/xflr5.htm 
[6] Floros M.W., Johnson W., Performance Analysis of the Slowed-Rotor Compound Helicopter Configuration, Journal of the American Helicopter Society. Presented at the AHS 4th Decennial Specialists' Conference on Aeromechanics, San Francisco, California, 21th - 23th January, 2004.

[7] Harwood P., Flying 'New Generation' Gyrocopter, A guide for converting pilots! http://www.gyrocopterschool.com/gyrocopter-autogyro-gyroplane/how-to-fly-gyros/

[8] http://airfoiltools.com/airfoil/details?airfoil=n8h12-il

[9] http://wirnikautorotacyjny.pl/, website of the project "Modern Gyroplane Main Rotor", (UDA-POIG.01.03.01-14-007/12), co-financed by the European Regional Development Fund under the Operational Programme Innovative Economy 2007-2013.

[10] Nocedal J. and Wright S.J., 2006, Numerical Optimization, Springer-Verlag, 2nd ed., Berlin - New York.

[11] Pietrosiński, M., 2015, "Wpływ geometrii profilu lotniczego łopaty wirnika głównego na osiągi wiatrakowca" (Eng. : "The Influence of the Main Rotor Blade Airfoil Geometry on the Gyroplane Performance"), Transactions of the Institute of Aviation, 4 (241), s. 62-72.

[12] Stalewski W., 2012, "Parametric Modelling of Aerodynamic Objects - the Key to Successful Design and Optimisation”, Aerotecnica Missili e Spazio. Italian Association of Aeronautics and Astronautics (AIDAA). 1/2 (90), March-June 2012.

[13] Stalewski W. and Żółtak J. 2012, “Optimisation of the Helicopter Fuselage with Simulation of Main and Tail Rotor Influence", in Proceedings of the 28th ICAS Congress of the International Council of the Aeronautical Sciences, ICAS, Brisbane, Australia, September 2012, ICAS, 1, pp. 256-266.

[14] Stalewski W., Projektowanie i optymalizacja aerodynamiczna wiropłatów, (Eng.: Aerodynamic Design and Optimisation of Rotorcraft). Wydawnictwa Naukowe Instytutu Lotnictwa, 2017.

[15] Stalewski W., 2013, "URANS Simulations of On or Near the Ground Flight of the Gyroplane", in Proceedings of 39th European Rotorcraft Forum, ERF, Moscow, 3-6 September 2013, Russian Helicopters, pp. 55-57.

[16] Stalewski W., Zalewski W., 2011, Analiza obliczeniowa własności aerodynamicznych wirnika nośnego wiatrakowca w stanie lotu ustalonego (autorotacji) (“Computational analysis of aerodynamic performance of gyroplane main rotor under cruise flight condition (autorotation)"), Prace Instytutu Lotnictwa, Nr 219. s. 269-279. (in Polish)

[17] Stalewski W., Zalewski W., 2011, Analiza wybranych stanów lotu wiatrakowca w oparciu o obliczeniowe charakterystyki aerodynamiczne jego komponentów ("Analysis of selected states of gyroplane flight based on computational aerodynamic characteristics of its components"), Prace Instytutu Lotnictwa, Nr 219. s. 280-288. (in Polish)

[18] Stalewski W., Zalewski W., 2011, Symulacja pracy wirnika nośnego wiatrakowca w początkowej fazie pionowego startu ("Computational simulation of operation of gyroplane main rotor in initial phase of vertical take-off”), Prace Instytutu Lotnictwa, Nr 219. s. 289-296. (in Polish)

[19] Stalewski W., Żółtak J., 2012, Optimisation of the Helicopter Fuselage with Simulation of Main and Tail Rotor Influence, Proceedings of the 28th ICAS Congress of the International Council of the Aeronautical Sciences, ICAS, Brisbane, Australia, 23 - 28 September, 2012. ICAS 2012 CD-ROM Proceedings. 
[20] Stivers L.S., Rice F.J., 1946, Aerodynamic Characteristics of Four NACA Airfoil Sections Designed for Helicopter Rotor Blades. National Advisory for Aeronutics. NACARB No. L5K02. http://naca.central.cranfield.ac.uk/reports/1946/naca-rb-15k02.pdf

[21] Szczepanik T., Dąbrowska J., 2009, Wiatrakowce, jako przewidywany kierunek rozwoju wiropłatów w XXI wieku ("Gyroplanes, as the predicted direction for the rotorcraft development in the 21st century"), Prace Instytutu Lotnictwa, Nr 201 (6/2009), s. 177-222. (in Polish)

[22] Wikipedia: https://en.wikipedia.org/wiki/Autogyro

\section{POPRAWA I OPTYMALIZACJA OSIĄGÓW WIATRAKOWCA}

\section{Streszczenie}

Celem pracy było zbadanie możliwości poprawy właściwości eksploatacyjnych lekkiego wiatrakowca, jak również zaproponowanie nowych lub ulepszonych rozwiązań zwiększających osiągi tego typu wiropłatów. Prace badawcze przeprowadzono w oparciu o metody Obliczeniowa Mechaniki Płynów, Mechaniki Lotu, Komputerowego Wspomagania Projektowania i Optymalizacji Inżynieryjnej. Wyniki zrealizowanych badań potwierdzają, że przy użyciu zaawansowanych metod obliczeniowych można znacznie poprawić właściwości osiągowe lekkiego wiatrakowca. Można to osiągnąć zarówno poprzez optymalizację konstrukcji wirnika nośnego jak i poprzez optymalizację strategii kontroli lotu wiatrakowca. Przedstawiono niekonwencjonalne podejście do optymalizacji wiropłatów, wyróżniające się tym, że funkcja celu była obliczana na podstawie komputerowej symulacji wybranych stanów lotu wiatrakowca. Jeden z nowo zaprojektowanych wirników został już przetestowany podczas prób w locie, które potwierdziły jego dobre osiągi i właściwości eksploatacyjne oraz przewagę tego wirnika nad konstrukcjami klasycznymi. Opracowana przez autora rodzina dedykowanych profili wiatrakowcowych stanowi konkurencyjną alternatywę w stosunku do klasycznych profili aerodynamicznych stosowanych zazwyczaj do konstrukcji łopat wiatrakowca. To samo odnosi się do łopat wirnika nośnego zbudowanych w oparciu o nowo zaprojektowane profile. W szczególności dotyczy to konstrukcji niekonwencjonalnych łopat wirnika charakteryzujących się zmiennymi wzdłuż rozpiętości: cięciwą i względną grubością przekrojów łopaty. Opracowana metodologia numerycznej optymalizacji strategii kontroli lotu podczas bezrozbiegowego startu wiatrakowca, prezentuje oryginalne podejście do tego typu problemów i może stanowić cenne narzędzie wspomagające proces szkolenia pilotów wiatrakowców.

Słowa kluczowe: osiągi wiropłatów, wiatrakowiec, bezrozbiegowy start, wirnik główny, projektowanie i optymalizacja. 